\title{
MENULIS TEKS PIDATO PERSUASIF, MOTIVASI BELAJAR, DAN PENDEKATAN SAINTIFIK DENGAN BANTUAN MEDIA POWTOON
}

Writing Persuasive Speech Texts, Learning Motivation and Scientific Approach with the Help of Powtoon Media

\author{
Ika Mustika, Alfa Mitri Suhara, Endri Luki Fauzi \\ IKIP Siliwangi \\ mestikasaja@ikipsiliwangi.ac.id
}

Naskah Diterima Tanggal 29 Januari 2020_Direvisi Akhir Tanggal 13 Februari 2021_Disetujui Tanggal 12 Juni 2021 doi: https://doi.org/10.26499/rnh.v10i1.3348

\begin{abstract}
Abstrak
Tujuan dari penelitian yaitu untuk mengetahui kemampuan menulis teks pidato persuasif dan motivasi belajar siswa SMP yang pembelajarannya menggunakan pendekatan saintifik dengan bantuan media Powtoon dibandingkan dengan yang menggunakan pendekatan saintifik, untuk mengetahui ada tidaknya hubungan antara motivasi belajar dengan kemampuan menulis teks pidato persuasif siswa SMP, dan untuk mengetahui kinerja siswa dalam implementasi pendekatan saintifik, menyelesaikan soal-soal pengetahuan, dan menyelesaikan tugas praktik menulis teks pidato persuasif. Metode yang digunakan dalam penelitian adalah quasi eksperimen dengan tipe nonequivalent control group design. Sampel pada penelitian ini yaitu siswa SMP yang berjumlah 50 orang. Berdasarkan data penelitian diperoleh hasil bahwa kelas eksperimen lebih baik dalam menulis teks pidato persuasif dibandingkan kelas kontrol. Pada data uji asosiasi antara kemampuan menulis teks pidato persuasif dengan motivasi berlajar ternyata pada kelas eksperimen diperoleh nilai Sig 0,058>0,05 dan di kelas kontrol diperoleh nilai Sig 0,357 >0,05. Hasil tersebut bermakna bahwa tidak ada asosiasi antara kemampuan menulis teks pidato persuasif dan motivasi belajar baik di kelas eksperimen ataupun kelas kontrol. Kinerja siswa pada saat mengimplementasikan pendekatan saintifik dengan bantuan media powtoon diperoleh hasil 86,66 \% hasil tersebut bermakna bahwa kinerja siswa sangat baik. Adapun kinerja siswa dalam kemampuannya dalam menulis teks pidato persuasif di kelas eksperimen yaitu ada dalam kategori baik, sedangkan di kelas kontrol yaitu dalam kategori kurang.
\end{abstract}

Kata-kata kunci: persuasi, motivasi belajar, saintifik, media powtoon

\begin{abstract}
The purpose of this research is to determine the ability to write persuasive speech text and learning motivation of junior high school students whose learning uses a scientific approach assisted by powtoon media compared to those using a scientific approach, to determine whether there is a relationship between learning motivation and the ability to write persuasive speech text of junior high school students, and to Knowing student performance in implementing the scientific approach, solving knowledge questions, and completing practical assignments to write persuasive speech texts. The method used in this study is a quasi-experimental type nonequivalent control group design. The sample in this study were 50 junior high school students. Based on the research data, it was found that the experimental class was better at
\end{abstract}


writing persuasive speech texts than the control class. In the association test data between the ability to write persuasive speech text and learning motivation, it turns out that in the experimental class the Sig value is $0.058>0.05$ and in the control class the sig value is 0.357> 0.05 . These results mean that there is no association between the ability to write persuasive speech texts and learning motivation in either the experimental class or the control class. The performance of students when implementing the scientific approach assisted by the powtoon media was $86.66 \%$. These results meant that the student's performance was very good. The student's performance in his ability to write persuasive speech texts in the experimental class was in the good category, while in the control class it was in the poor category.

Keywords: persuasion, Learning Motivation, scientific, powtoon media

How to Cite: Mustika, Ika, Alfa Mitri Suhara, dan Endri Luki Fauzi. (2021). Menulis Teks Pidato Persuasif, Motivasi Belajar, dan Pendekatan Saintifik dengan Bantuan Media Powtoon. Ranah: Jurnal Kajian Bahasa. 10(1). 144-152. doi: https://doi.org/10.26499/rnh.v10i1.3348

\section{PENDAHULUAN}

Pengajaran bahasa Indonesia mempunyai ruang lingkup dan tujuan untuk menumbuhkan serta mengembangkan potensi yang dimiliki individu dalam mengungkapkan ide dan gagasannya dengan menggunakan bahasa yang baik dan benar. Salah satu materi pembelajaran yang dapat mengembangkan kemampuan tersebut yaitu menulis teks pidato persuasif karena merupakan seni mengungkapkan pendapat secara jelas dan logis. Selain itu, pidato persuasif merupakan bagian dari eksposisi yang digunakan untuk meyakinkan pembaca atau pendengar dengan menyajikan argumen yang logis dari satu sudut pandang. Srianah (2020:2) menyatakan pidato persuasif adalah jenis pidato yang bertujuan untuk menarik perhatian para pendengar, memengaruhi, serta bersifat mengajak atau membujuk para pendengar agar mereka menjadi yakin dan mau melakukan sesuai dengan tujuan pidato tersebut.

Praktinya pembelajaran menulis teks pidato persuasif mengalami beberapa kendala. Gazali (2019:5) mengemukakan bahwa pengungkapan ide menulis teks pidato persuasif serta pemahaman siswa terhadap ciri-ciri pidato persuasif belum optimal. Sukanah \& Rahayu (2021:134) mengemukakan model dan media pembelajaran yang digunakan guru cenderung monoton, sehingga pembelajaran menulis teks pidato persuasif tidak menarik. Selain itu, motivasi siswa terhadap keterampilan menulis teks pidato masih rendah. Jatu \& Seno (2020:9) menjelaskan rendahnya motivasi siswa dalam menulis teks pidato disebabkan siswa merasa belum membutuhkan keterampilan menulis teks pidato persuasif tersebut.

Melihat permasalahan tersebut, guru dituntut inovatif, kreatif dan memberikan motivasi pada saat mengajar supaya siswa tidak merasa jenuh pada saat menerima dan dapat memahami materi yang disampaikan. Guru juga seharusnya lebih banyak memberikan latihan dalam menulis agar siswa terbiasa dalam menuangkan ide dan gagasannya ke dalam bentuk tulisan. Keterampilan menulis pada dasarnya muncul karena terbiasanya siswa dalam menulis dan harus dilatih secara berkesinambungan, termasuk menulis teks pidato persuasif.

Salah satu strategi untuk mengatasi permasalahan di atas dengan menerapkan Pendekatan saintifik dengan bantuan media powtoon. Penerapan pendekatan saintifik didorong penelitian Sumayasa (2015:7) hasil belajar Bahasa Indonesia siswa dengan menerapkan pendekatan saintifik lebih baik daripada hasil belajar Bahasa Indonesia siswa dengan menerapkan model pembelajaran konvensional. Sejalan dengan penelitian Sari \& Listiadi (2018:5) media pembelajaran powtoon sebagai bahan pengamatan dalam implementasi pendekatan saintifik sangat layak sebagai media pembelajaran yang dikembangkan. Suaedi $(2018 ; 247)$ menyatakan powtoon merupakan suatu layanan aplikasi online. Aplikasi powtoon 
merupakan bagian dari pemanfaatan teknologi informasi dan komunikasi. Powtoon bisa digunakan untuk membuat paparan tulisan, animasi kartun bergerak, gambar, dan musik. Media pembelajaran ini juga menekankan proses berfikir secara kritis dalam mencari dan menemukan sendiri jawaban dari suatu masalah yang dipertanyakan oleh siswa dengan media berupa powtoon.

Berkaitan dengan itu, fokus permasalahan penelitian ini yaitu: 1) kemampuan menulis teks pidato persuasif dan motivasi belajar siswa SMP yang pembelajarannya menggunakan pendekatan saintifik dengan bantuan media powtoon, 2) hubungan antara motivasi belajar dengan kemampuan menulis teks pidato persuasif, serta 3) gambaran kinerja siswa dalam implementasi dan kemampuan menyelesaikan soal dan tugas praktik menulis teks pidato persuasif.

\section{LANDASAN TEORI}

Mengacu Kurikulum 2013 mata pelajaran Bahasa Indonesia di Sekolah Menengah Pertama, teks pidato persuasif merupakan salah satu jenis teks yang harus dikuasai siswa. Srianah (2020:2) menjelaskan teks pidato persuasif adalah teks atau naskah yang disusun/dipersiapkan sebelum berpidato, yang bertujuan menarik perhatian para pendengar, memengaruhi, serta bersifat mengajak atau membujuk para pendengar agar mereka menjadi yakin dan mau melakukan sesuai dengan tujuan pidato tersebut.

Selanjutnya Srianah (2020:3) menyatakan urutan pidato adalah sebagai berikut: (1) Salam pembuka dan menyapa hadirin; (2) Pendahuluan yang biasanya dalam bentuk ucapan terima kasih, atau ungkapan kegembiraan atau rasa syukur; (3) Isi pidato yang ditulis dengan jelas dengan menggunakan bahasa Indonesia yang baik dan benar dengan gaya bahasa yang menarik; (4) Kesimpulan dari isi pidato supaya mudah diingat oleh hadirin; (5) Harapan yang berisi anjuran atau ajakan kepada pendengar untuk melaksanakan isi pidato; dan (6) Salam penutup.

Sumiati dan Asra (2009:59) menjelaskan motivasi belajar adalah sesuatu yang mendorong siswa untuk berprilaku yang langsung menyebabkan munculnya prilaku dalam belajar. Siswa akan melakukan suatu proses belajar betapa pun beratnya jika ia mempunyai motivasi tinggi. Sejalan dengan pendapat Astuti dan Trivia (2013:67) bahwa motivasi belajar adalah sesuatu yang mendorong, menggerakan, dan mengarahkan siswa dalam belajar. Sedangkan menurut Maslow (dalam Nashar, 2004:42) motivasi belajar juga merupakan kebutuhan untuk mengembangkan kemampuan diri secara optimum, sehingga mampu berbuat yang lebih baik, berprestasi dan kreatif. Jadi motivasi belajar adalah suatu tindakan mendorong dan mengarahkan peserta didik dalam belajar sehingga peserta didik mampu memecahkan masalah yang dihadapinya dan berprilaku aktif (positif) saat belajar serta berprilaku lebih baik. Uno (2011:23) menjelaskan indikator motivasi belajar dapat diklasifikasikan sebagai berikut: 1) adanya hasrat dan keinginan berhasil, 2) adanya dorongan dan kebutuhan dalam belajar, 3) adanya harapan dan cita-cita masa depan, 4) adanya pengahrgaan dalam belajar, 5) adanya kegiatan yang menarik dalam belajar, dan 6) adanya lingkungan belajar yang kondusif. Sedangkan menurut Dimyati dan Mudjiono (2009: 97) indikator motivasi belajar antara lain: 1) cita-cita, 2) kemampuan siswa, 3) kondisi siswa, dan 4) kondisi lingkungan siswa. Berdasarkan pendapat di atas maka dapat disimpulkan bahwa indikator motivasi belajar adalah sebagai berikut: adanya keinginan untuk belajar, berprilaku aktif (positif) saat belajar, mencari informasi atas ilmu yang belum dipahami sebagai bekal pengetahuan, berusaha untuk memperbiki diri supaya lebih baik, tidak putus asa ketika apa yang diharapkan belum tercapai, dan berprilaku mandiri.

Daryanto (2014: 51) mengemukakan pembelajaran dengan pendekatan saintifik adalah proses pembelajaran yang dirancang sedemikian rupa agar siswa secara aktif mengkonstruksi 
konsep, Hukum atau prinsip melalui tahapan-tahapan mengamati (untuk mengidentifikasi atau menemukan masalah), merumuskan masalah, mengajukan pertanyaan atau mengajukan hipotesis, mengumpulkan data dengan berbagai teknik, menganalisis data, menarik kesimpulan dan mengkomunikasikan konsep, hukum atau prinsip-prinsip yang ditemukan. Pendekatan saintifik menurut Kurniasih (2014:29) adalah proses pembelajaran yang dirancang sedemikian rupa agar peserta didik secara aktif mengkonstruksikan konsep pembelajaran melalui tahapantahapan mengamati (untuk mengidentifikasi atau menemukan masalah), merumuskan masalah,mengajukan atau merumuskan hipotesis, mengumpulkan data dengan berbagai teknik, menganalisis data, menarik kesimpulan dan mengomunikasikan konsep. Sementara itu Majid (2014:193) mengemukakan bahwa pendekatan saintifik meliputi mengamati, menanya, mencoba, mengolah, menyajikan, menyimpulkan, dan menciptkan. Berdasarkan pendapat yang diutarakan oleh para ahli tersebut dapat disimpulkan bahwa pendekatan saintifik adalah proses pembelajaran yang dirancang sedemikian rupa agar peserta didik secara aktif mampu mengenal dan memahami berbagai materi menggunakan pendekatan ilmiah bahwa informasi bisa berasal dari mana saja, kapan saja, tidak tergantung pada informasi searah dari guru. Peserta didik dituntut untuk mandiri dalam menggali informasi.

Hosnan (dalam Atnuri \& Prastyo, 2016:15) menjelaskan pembelajaran dengan metode saintifik memiliki karakteristik sebagai berikut: 1) berpusat pada siswa, 2) melibatkan keterampilan proses sains dalam mengonstruksi konsep, hukum atau prinsip, 3) melibatkan proses-proses kognitif yang potensial dalam merangsang perkembangan intelek, khususnya keterampilan berpikir tingkat tinggi siswa, dan 4) dapat mengembangkan karakter siswa.

Sani (2018:53) mengemukakan langkah-langkah pendekatan saintifik adalah: 1) mengamati atau observasi, 2) mengajukan pertanyaan, 3) melakukan eksperimen atau memeroleh informasi, 4) mengasosiasi/menalar, 5) membangun atau mengembangkan jaringan dan berkomunikasi. Musfiqon dan Nurdyansyah (2015:38) mengemukakan langkah-langkah pendekatan saintifik sebagai berikut: 1) mengamati, 2) menanya, 3) mengumpulkan Informasi, 4) mengasosiasi, dan 5) komunikasi. Sedangkan menurut Kurniasih (2014:38) langkah-langkah pendekatan saintifik adalah sebagai berikut: 1) mengamati, 2) menanya, 3) mencoba, 4) Menalar, 5) menarik kesimpulan, dan 6) mengomunikasikan.

Terdapat perbedaan pendapat dalam langkah-langkah yang dikemukakan oleh Sani (2018), Kurniasih (2014), Musfiqon dan Nurdyansyah (2015). Sani, Musfiqon dan Nurdyansyah mengemukakan bahwa dalam langkah-langkah pendekatan saintifik itu ada 5 tahap, sedangkan yang dikemukakan oleh Kurniasih bahwa langkah-langkah pendekatan saintifik ada 6. Jika ditinjau dari letak perbedaannya hanya ada satu yaitu dalam menarik kesimpulan yang dikemukakan oleh Kurniasih sedang yang dikemukakan oleh Sani, Musfiqon, dan Nurdyansyah tidak ada langkah untuk menarik kesimpulan. Jadi pada dasarnya langkahlangkah saintifik tidak jauh berbeda setelah memperhatikan pendapat yang dikemukakan oleh Sani, Musfiqon, Nurdyansyah, dan Kurniasih. Adapun langkah-langkah pendekatan saintifik yang digunakan pada penelitian ini sebagai berikut: mengamati (observasi), menanya, menalar, mencoba, dan mengomunikasikan.

Media powtoon merupakan layanan online untuk membuat sebuah paparan yang memiliki fitur animasi sangat menarik diantaranya animasi tulisan tangan, animasi kartun, dan efek transisi yang lebih hidup serta pengaturan time line yang sangat mudah. Putri (2016: 25) mengemukakan manfaat pembelajaran media powtoon sebagai berikut: 1) memperjelas penyajian pesan agar tidak terlalu bersifat verbalistis (dalam bentuk kata-kata tertulis atau lisan belaka), 2) mengatasi keterbatasan ruang, waktu dan daya indera, dan 3) kejadian atau peristiwa yang terjadi di masa lalu bisa ditampilkan lagi lewat rekaman film, video, film bingkai, foto mau-pun secara verbal. 
Selanjutnya Putri (2016: 26) mengemukakan di dalam setiap media pembelajaran pasti mempunyai kekurangan dan kelebihan. Adapun kekurangan media pembelajaran powtoon sebagai jenis media pembelajaran audio-visual yakni 1) ketergantungan pada ketersedian dukungan sarana teknologi, 2) harus disesuaikan dengan sistem dan kondisi yang ada, 3) mengurangi kreativitas dan inovasi dari jenis media pembelajaran lainnya, dan 4) membutuhkan dukungan SDM yang profesional untuk mengoprasikannya. Sementara itu kelebihannya 1) Interaktif, 2) mencakup segala aspek indera, 3) penggunaannya praktis, 4) kolaboratif, 5) lebih variatif, 6) dapat memberikan feedback, dan 7) memotivasi.

\section{METODE PENELITIAN}

Jenis penelitian ini adalah penelitian kuantitatif. Metode yang digunakan yaitu metode quasi experimental tipe nonequivalent control graup design. Desain ini menggunakan dua kelompok sampel yang tidak dipilih secara acak serta dianggap sama dalam semua aspek yang relevan dan perbedaannya hanya terdapat pada perlakuan yang diberikan pada kelompok eksperimen.

Populasi penelitian ini adalah siswa kelas IX SMP di salah satu Kota Cimahi yang terdaftar pada tahun ajaran 2019/2020. Jumlah siswa yang terdaftar 125 orang yang tersebar pada lima kelas. Pengambilan sampel penelitian dilakukan dengan teknik purposive sampling. Kelas IX A sebagai kelas eksperimen, dan kelas IX E sebagai kelas kontrol. Masing-masing kelas berjumlah 25 orang.

Instrumen yang digunakan dalam penelitian ini tes pengetahuan menulis teks pidato sejumlah 20 butir soal pilihan ganda, dan 1 soal esai tes keterampilan menulis teks pidato. Sedangkan tes untuk mengukur motivasi belajar adalah angket tertutup dengan pernyataan sejumlah 20 butir. Instrumen telah divalidasi ahli dan melalui perhitungan kalibrasi instrumen dengan menggunakan bantuan software anates.

Teknik pengumpulan data penelitian dilakukan di kelas eksperimen dan kelas kontrol. Uji persyaratan analisis yang dilakukan dalam penelitian ini adalah uji normalitas dan uji homogenitas data. Uji normalitas data dilakukan dengan menggunakan uji KolmogorovSmirnov. Setelah dilakukan kedua uji prasyarat pada data pretest dan posttest serta sampel dinyatakan normal dan homogen maka dilanjutkan dengan uji hipotesis. Uji hipotesis yang digunakan adalah uji-t ( $t$-test).

\section{PEMBAHASAN}

\section{Kemampuan Menulis Teks Pidato Persuasif Sebelum dan Sesudah Diberi Perlakuan}

Data yang diperoleh dalam penelitian pada kelas eksperimen dan kolas kontrol dianalisis melalui tahap uji normalitas dan uji signifikansi perbedaan rata-rata. Pada tes awal (prettes) dan tes akhir (posttest) diperoleh data sebagai berikut.

Tabel 1

Uji Mann Witney data Prates

\begin{tabular}{lllr}
\hline & \multicolumn{2}{c}{ Test Statistics $^{\mathrm{a}}$} & \multicolumn{2}{c}{$\begin{array}{c}\text { Pretes_Kemampuan } \\
\text { menulis }\end{array}$} \\
\hline Monte Carlo Sig. (2-tailed) & Sig. & & $.858^{\mathrm{b}}$ \\
& $95 \%$ Confidence Interval & Lower Bound & .851 \\
& & Upper Bound & .865 \\
Monte Carlo Sig. (1-tailed) & Sig. & & $.422^{\mathrm{b}}$ \\
& $95 \%$ Confidence Interval & Lower Bound & .412 \\
& & Upper Bound & .431 \\
\hline
\end{tabular}


Tabel 1, hasil nilai Sig pada Monte Carlo (1-tailed) adalah 0.422. Hal ini menjelaskan bahwa nilai Sig > 0.05 maka dapat di simpulkan bahwa $\mathrm{H}_{0}$ diterima otomatis $\mathrm{H}_{\mathrm{A}}$ ditolak. Jadi, tidak terdapat berbedaan antara kelompok eksperimen dan kelompok kontrol.

Tabel 2

Uji t' (Uji t aksen)

\begin{tabular}{clllllll}
\hline \multicolumn{8}{c}{ Independent Sampel Test } \\
\hline \multirow{7}{*}{$\begin{array}{c}\text { Posttest } \\
\text { Kemampuan }\end{array}$} & \multicolumn{7}{c}{ Levene's Test for Equality of Variances } \\
\cline { 2 - 8 } & $\begin{array}{l}\text { Equal variances } \\
\text { assumed } \\
\begin{array}{l}\text { Equal variances not } \\
\text { assumed }\end{array}\end{array}$ & & & Sig. & T & Df & Sig. (2-tailed) \\
\hline
\end{tabular}

Tabel 2, bahwa data tersebut menunjukan adanya perbedaan antara nilai pretest dan nilai posttest. Karena pada perhitungan posttest masih menggunakan uji 2 pihak (2-tailed) maka menggunakan uji ( 1 -tailed) dengan cara membagi 2 nila signifikansinya $(0.000 / 2)$. terdapat nilai Sig $<0.05$ yaitu 0. Berdasarkan data tersebut dapat dikatakan bahwa $\mathrm{H}_{\mathrm{A}}$ diterima dan $\mathrm{H}_{0}$ ditolak.

Berdasarkan hasil analisis terhadap kemampuan siswa dalam pembelajaran menulis teks pidato persuasif, ternyata diperoleh hasil bahwa siswa kelas eksperimen yang menggunakan pendekatan saintifik dengan bantuan media powtoon lebih baik dibandingkan kelas kontrol yang menggunakan pendekatan saintifk. Hasil tersebut terbukti dari hasil uji SPSS yang menunjukan bahwa nilai Sig 2 tailed adalah $0,000<0,05$ yang berarti $\mathrm{H}_{0}$ telah diolak. Hasil tersebut menunjukkan bahwa siswa yang menggunakan pendekatan saintifik dengan bantuan media powtoon memiliki kemampuan menulis teks pidato persuasif yang lebih baik dibandingkan kelas yang menggunakan pendekatan saintifik.

\section{Motivasi Belajar Sebelum dan Setelah Diberi Perlakuan}

Motivasi dalam pembelajaran perlu dilakukan dan diberikan kepada siswa, sebagaimana dengan pendapat Astuti dan Trivia (2013:67), bahwa motivasi belajar adalah sesuatu yang mendorong, menggerakan, dan mengarahkan siswa dalam belajar. Berdasarkan hasil sebaran angket yang diberikan kepada sampel pada kelas eksperimen dan kelas kontrol sebelum diberikan perlakuan diketahui dari hasil uji Mann Whitney dapat dilihat nilai Sig pada Monte Carlo (1-tailed) adalah 0.113. Hal ini menjelaskan bahwa nilai Sig > 0.05 maka dapat disimpulkan bahwa $\mathrm{H}_{0}$ diterima otomatis $\mathrm{H}_{\mathrm{A}}$ ditolak. Sedangkan angket yang diberikan pada kelas eksperimen dan kelas kontrol setelah diberikan perlakuan diketahui nilai Sig pada Monte Carlo (1-tailed) adalah 0.002. Hal ini menjelaskan bahwa nilai Sig < 0.05. maka dapat disimpulkan bahwa $\mathrm{H}_{0}$ ditolak otomatis $\mathrm{H}_{\mathrm{A}}$ diterima.

Berdasarkan hasil analisis tersebut diketahui motivasi belajar siswa dalam pembelajaran menulis teks pidato persuasif bahwa siswa kelas eksperimen yang menggunakan pendekatan saintifik dengan bantuan media powtoon lebih baik dibandingkan kelas kontrol yang menggunakan pendekatan saintifik. Hasil tersebut terbukti dari hasil uji SPSS yang menunjukan bahwa nilai Sig 1 tailed adalah 0,002 < 0,05 yang berarti $\mathrm{H}_{0}$ telah diolak. Artinya siswa yang menggunakan pendekatan saintifik dengan bantuan media powtoon memiliki motivasi yang lebih baik dibandingkan kelas yang menggunakan pendekatan saintifik.

\section{Korelasi Kemampuan Menulis Teks Pidato Persuasif dan Motivasi Belajar Kelas Eksperimen dan Kelas Kontrol}

Pada bagian ini peneliti akan menyampaikan keterkaitan antara motivasi belajar dan keterampilan menulis teks pidato persuasif siswa dalam pembelajaran teks pidato persuasif. 
Berdasarkan hasil penilaian motivasi belajar dan menulis teks pidato persuasif di kelas eksperimen dan kelas kontrol diperoleh data sebagai berikut.

Tabel 3

Uji Asosiasi Motivasi Belajar dan Kemampuan Menulis

\section{Chi-Squae Tests}



Tabel 3, diperoleh nilai Sig $=0,058>0,05$, sehingga $\mathrm{H}_{0}$ diterima. Oleh karena itu, dapat disimpulkan bahwa tidak terdapat hubungan antara motivasi belajar dengan kemampuan menulis teks pidato persuasif.

Tabel 4

Uji Chi-Squeare Tests

Chi-Square Tests

\begin{tabular}{|c|c|c|c|c|c|c|c|c|c|}
\hline & \multirow[b]{3}{*}{ Value } & \multirow[b]{3}{*}{ Df } & \multirow{3}{*}{$\begin{array}{c}\text { Asymptotic } \\
\text { Significance } \\
\text { (2-sided) }\end{array}$} & \multicolumn{3}{|c|}{$\begin{array}{l}\text { Monte Carlo Sig. (2- } \\
\text { sided) }\end{array}$} & \multicolumn{3}{|c|}{$\begin{array}{l}\text { Monte Carlo Sig. (1- } \\
\text { sided) }\end{array}$} \\
\hline & & & & \multirow[b]{2}{*}{$\begin{array}{l}\text { Signifi } \\
\text { cance }\end{array}$} & \multicolumn{2}{|c|}{$\begin{array}{l}95 \% \text { Confidence } \\
\text { Interval }\end{array}$} & \multirow[b]{2}{*}{$\begin{array}{l}\text { Signifi } \\
\text { cance }\end{array}$} & \multicolumn{2}{|c|}{$\begin{array}{l}\text { 95\% Confidence } \\
\text { Interval }\end{array}$} \\
\hline & & & & & $\begin{array}{l}\text { Lower } \\
\text { Bound }\end{array}$ & $\begin{array}{l}\text { Upper } \\
\text { Bound }\end{array}$ & & $\begin{array}{l}\text { Lower } \\
\text { Bound }\end{array}$ & $\begin{array}{l}\text { Upper } \\
\text { Bound }\end{array}$ \\
\hline Pearson Chi-Square & $5.469^{a}$ & 2 & .065 & $.200^{\mathrm{b}}$ & .043 & .357 & & & \\
\hline Likelihood Ratio & 3.899 & 2 & .142 & $.200^{\mathrm{b}}$ & .043 & .357 & & & \\
\hline Fisher's Exact Test & 5.346 & & & $.200^{\mathrm{b}}$ & .043 & .357 & & & \\
\hline Linear-by-Linear & $2.201^{\mathrm{c}}$ & 1 & .138 & $.200^{\mathrm{b}}$ & .043 & .357 & $.200^{\mathrm{b}}$ & .043 & .357 \\
\hline \multicolumn{10}{|l|}{ Association } \\
\hline $\mathrm{N}$ of Vali Cases & 25 & & & & & & & & \\
\hline
\end{tabular}

Tabel 4 diperoleh nilai $\mathrm{Sig}=0,357>0,05$, sehingga $\mathrm{H}_{0}$ diterima. Oleh karena itu, dapat disimpulkan bahwa tidak terdapat hubungan antara motivasi belajar dengan kemampuan menulis teks pidato persuasif.

Berdasarkan hasil analisis terhadap asosiasi kemampuan menulis dan motivasi belajar di kelas kontrol dan kelas eskperimen ternyata terdapat hasil bahwa tidak ada keterkaitan antara kemampuan menulis teks pidato persuasif dan motivasi belajar siswa dalam menulis teks pidato persuasif.

\section{Gambaran Kinerja Siswa}

Peneliti pada bagian ini akan mendeskripsikan implementasi pembelajaran menulis teks pidato persuasif serta gambaran menyelesaikan soal-soal pengetahuan dan keterampilan di kelas eksperimen dan kelas kontrol. Tahap pembelajaran menulis teks piato persuasif dimulai dengan melakukan tes awal (pretest) untuk mengetahui kemampuan awal siswa. Langkah selanjutnya adalah perlakuan (treatment) memberikan pembelajaran menulis teks pidato persuasif. Langkah yang terakhir melakukan tes akhir (posttest) untuk mengetahui kemampuan siswa terhadap pembelajaran menulis teks pidato persuasif setelah diberi perlakuan 
pembelajaran menulis teks pidato persuasif penelitian ini berguna bagi peneliti untuk menjawab permasalahan yang dikemukakan serta mendapatkan hasil untuk menjawab hipotesis penelitian.

\section{1) Implementasi Pembelajaran Saintifik dengan Bantuan Media Powtoon}

Aktivitas guru pada saat mengajar merupakan hal yang akan menunjang keberhasilan siswa dalam menempuh pembelajaran. Maka, peneliti merumuskan aspek yang akan di observasi mengenai aktivitas guru dalam mengimplementasikan pembelajaran menulis teks pidato persuasif dengan menggunakan pendekatan saintifik dengan bantuan media powtoon. Pada tahap ini, peneliti melibatkan 2 orang observer untuk membantu menilai aktivitas guru pada saat mengajar. Pada saat pembelajaran dilaksanakan, observer masuk ke dalam kelas dan menempati tempat yang sudah disediakan oleh peneliti untuk menilai aktivitas guru pada saat mengajar. Observer menilai aktivitas guru diawali dari kegiatan pendahuluan, kegiatan inti, dan kegiatan penutup. Berdasarkan data yang diperoleh dari observer satu adalah $88,33 \%$ dan dua adalah $91,88 \%$, maka persentase aktivitas guru dalam pembelajaran menulis teks pidato persuasif dengan menggunakan pendekatan saintifik dengan bantuan media powtoon dapat disimpulkan bahwa aktivitas guru dalam pembelajaran menulis teks pidato persuasif dengan menggunakan pendekatan saintifik dengan bantuan media powtoon dapat dikategorikan baik. Selain aktivitas guru, observer mengamati juga aktivitas siswa. Adapum hasil yang diperoleh dari observer satu adalah $85 \%$ dan dua adalah 88,33\%, maka persentase aktivitas siswa dalam pembelajaran menulis teks pidato persuasif dengan menggunakan pendekatan saintifik dengan bantuan media powtoon dapat disimpulkan bahwa aktivitas siswa dalam pembelajaran menulis teks pidato persuasif dengan menggunakan pendekatan saintifik dengan bantuan media powtoon dapat dikategorikan baik.

2) Gambaran Siswa dalam Menyelesaikan Soal Pengetahuan dan Keterampilan Menulis Teks Pidato Persuasif

Soal berperan penting sebagai alat mengukur pengetahuan dan keterampilan siswa sehingga soal yang dibuat harus memenuhi kriteria. Menurut Arikunto (2017:222) soal yang baik adalah soal yang tidak terlalu mudah atau tidak terlalu sukar. Soal yang terlalu mudah tidak merangsang siswa untuk mempertinggi usaha untuk memecahkannya. Sebaliknya soal yang terlalu sukar akan menyebabkan siswa menjadi putus asa dan tidak mempunyai semangat untuk mencoba lagi karena di luar jangkauan. Berdasarkan nilai rata-rata di kelas eksperimen secara keseluruhan dalam menulis teks pidato persuasif diperoleh nilai 68,2. Berdasarkan hasil penilaian kemampuan menulis teks pidato persuasif di kelas eksperimen ternyata terdapat satu siswa dengan kategori sangat baik. Terdapat enam siswa dengan kategori baik. Terdapat tiga belas siswa dengan kategori cukup. Terdapat lima siswa dalam kategori kurang. Sedangkan nilai rata-rata di kelas kontrol diperoleh nilai 49,1. Berdasarkan hasil penilaian kemampuan menulis teks pidato persuasif di kelas kontrol ternyata tidak terdapat siswa dengan kategori sangat baik dan baik. Terdapat sembilan siswa dengan kategori cukup. Terdapat enam belas siswa dengan kategori kurang. Kemudian penilaian pengetahuan nilai rata-rata yang paling rendah adalah pada aspek menentukan kalimat ajakan untuk menutup pidato persuasif. Sedangkan pada penilaian keterampilan nilai rata-rata yang paling rendah adalah pada aspek kaidah kebahasan meliputi penggunaan huruf kapital, tanda baca, struktur kalimat, dan ejaan.

\section{PENUTUP}

Analisis data dan pembahasan yang telah dikemukakan sebelumnya dapat diketahui bahwa kemampuan menulis teks pidato persuasif dan motivasi belajar siswa pada kelas eksperimen yang menggunakan pendekatan saintifik dengan bantuan media powtoon lebih baik dibandingkan kelas kontrol yang menggunakan pendekatan saintifik. Namun, hasil analisis 
kemampuan menulis teks pidato persuasif dengan motivasi belajar siswa, ternyata tidak terdapat asosiasi, baik di kelas eksperimen maupun kelas kontrol. Sedangkan kinerja siswa dalam mengimplementasi pembelajaran dengan menggunakan pendekatan saintifik dengan bantuan media powtoon telah terlaksana dengan baik. Adupun nilai rata-rata yang diperoleh adalah 68,2 dengan rincian satu siswa yang memiliki kemampuan menulis teks pidato persuasif dengan kategori sangat baik. Siswa yang termasuk ke dalam kategori baik terdapat enam orang. siswa yang termasuk ke dalam kategori cukup terdapat tiga belas orang. Siswa yang termasuk ke dalam kategori kurang terdapat lima orang. Secara keseluruhan nilai rata-rata pada kelas kontrol diperoleh nilai 49,1. Pada kelas kontrol tidak terdapat nilai dengan kategori sangat baik dan baik. Siswa dengan kategori cukup terdapat sembilan orang. Siswa dengan kategori kurang terdapat enam belas orang. Dengan demikian, pendekatan saintifik dengan bantuan media powtoon hendaknya dijadikan sebagai alternatif para guru dalam pembelajaran tentang teks pidato persuasif di sekolah. Terutama bagi siswa yang mengalami kesulitan pada aspek kaidah kebahasaan.

\section{DAFTAR PUSTAKA}

Arikunto, S. (2017). Dasar-Dasar Evaluasi Pendidikan. Yogyakarta: Bina Aksara

Astuti, dan Trivia. (2013). Metode Berhitung Lebih Cepat Jarimatika. Jakarta: Lingkar Media.

Atnuri, A., \& Prastyo, D. (2016). Pengaruh Pembelajaran Saintifik Model Problem Based Learning (PBL) dan Project Based Learning (PjBL) Terhadap Hasil Belajar Mahasiswa Jurusan PGSD Unipa Surabaya Pada Pokok Bahasan Ham. Wahana, 67(2), 13-19. https://doi.org/10.36456/wahana.v67i2.495

Dimyati dan Mujiono. (2009). Belajar dan Pembelajaran. Jakarta: Rineka Cipta

Daryanto. (2014). Pendekatan Pembelajaran Saintifik Kurikulum 2013. Yogyakarta: Penerbit Gava Media.

Gazali, H. (2019). Peningkatan Kemampuan Menulis Naskah Pidato Melalui Model Pembelajaran Pelatihan Kesadaran (Awareness Training). Jurnal Konfiks. 6(1), 34-45. https://doi.org/10.26618/jk.v6i1.167

Jatu, A., \& Seno, R. (2020). Pengaruh Motivasi Belajar dan Kemampuan Menyimak terhadap Keterampilan Menulis Teks Pidato (Survei pada SMA Negeri di Kota Cilegon) Universitas Indraprasta PGRI. Diskursus: Jurnal Pendidikan Bahasa Indonesi. 3(1), 9-17. https://doi.org/10.30998/diskursus.v3i01.6679

Kurniasih, I \& Sani, Berlin. (2014). Implementasi Kurikulum 2013 Konsep dan Penerapan. Surabaya: Kata Pena.

Majid, A. (2014). Strategi Pembelajaran. Bandung: PT Remaja Rosdakarya.

Musfiqon dan Nurdyansyah (2015). Pendekatan Pembelajaran Saintifik. Sidoarjo: Nizamia Learning Center

Nashar (2004). Peranan Motivasi dan Kemampuan Awal dalam Kegiatan Pembelajaran. Jakarta: Delia press.

Sardiman. (2011). Interaksi dan Motivasi Belajar Mengajar. Jakarta: Rajawali Pers

Sani, R. A. (2018). Pembelajaran Saintifik Untuk Implementasi Kurikulum 2013. Jakarta: Bumi Angkasa.

Sari, N., \& Listiadi, A. (2018). Penerapan Model Discovery Learning Menggunakan Media Powtoon Untuk Meningkatkan Hasil Belajar Siswa Mata Pelajaran Dasar Perbankan Kelas X Ak I SMK Negeri Mojoagung. Jurnal Pendidikan Akuntansi, 6(3), 345-349.

Srianah, M. (2020). Kartu Pintar Untuk Peningkatan Prestasi Belajar Berpidato Persuasif Kelas IX SMP Negeri 1 Sukapura Kabupaten Probolinggo. JIRA: Jurnal Inovasi Dan Riset Akademik, 1(1), https://doi.org/10.47387/jira.v1i1.18

Suaedi, H. (2018). Media Pembelajaran Berbasis ICT dengan Aplikasi Powtoon Pada Materi 
Identifikasi Unsur Intrinsik Teks Drama. Prosiding Seminar Nasional SAGA\#1: Sastra, Pedagogik dan Bahasa, 247-258.

Sukanah, D., \& Rahayu, G. D. S. (2021). Metode Pembelajaran Inqury dalam Meningkatkan Kemampuan Menulis Teks Pidato. COLLASE. 04(01), 134-141. https://www.journal.ikipsiliwangi.ac.id/index.php/collase/article/view/4896

Sumayasa, I. dkk. (2015). Pengaruh Implementasi Pendekatan Saintifik Terhadap Motivasi Belajar dan Hasil Belajar Bahasa Indonesia Pada Siswa Kelas VI Di Sekolah Dasar Se Gugus VI Kecamatan Abang, Karangasem. Jurnal Pendidikan Dasar Ganesha, 5(1), 124471.

Sumiati dan Asra. (2009). Metode Pembelajaran. Bandung: CV. Wacana Prima

Uno, H.B. (2011). Teori Motivasi dan Pengukurannya. Jakarta: Bumi Aksara.

Putri, F. S. (2016). Pembelajaran Memproduksi Teks Negosiasi Berdasarkan Powtoon dengan Menggunakan Metode Inkuiri Pada Siswa Kelas X SMK Negeri 4 Bandung Tahun Pelajaran. Program Studi Pendidikan Bahasa, Sastra Indonesia dan Daerah. Fakultas Keguruan dan Ilmu Pendidikan. Universitas Pasundan Bandung. 